\title{
Keratolysis Exfoliativa: Description of a Case Report
}

\section{Queratólise Esfoliativa: Descrição de um Caso Clínico}

Sónia Silva², Isabel Mendes², Maria José Dinis²

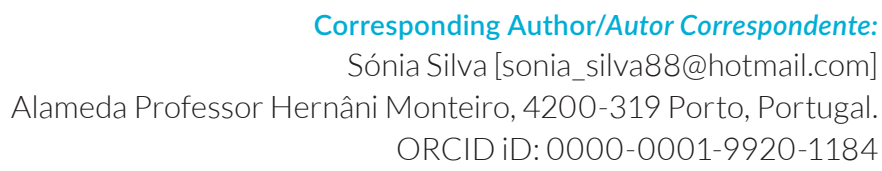

KEYWORDS: Child; Dermatitis, Exfoliative; Hand Dermatoses; Skin Diseases, Genetic

PALAVRAS-CHAVE: Criança; Dermatite Esfoliativa; Dermatopatias Genéticas; Dermatoses da Mão

An 8 year-old boy, previously healthy, presented on the emergency department, during the summer, with air-filled blisters on the volar aspect of the extremities of fingers on the hands (Fig. 1). On follow-up as an outpatient, he showed resolution of the first lesions but with various relapses associated with contact with water for a long period of time, showing posterior peeling of the skin and posterior resolution. What is your diagnosis?

The diagnosis of keratolysis exfoliativa was established and treatment was conducted with emollient cream.

Keratolysis exfoliativa, also known as dyshidrosis lamelosa sicca, was first described by Caryon in 1903. ${ }^{1}$ This dermatosis affects the palmoplantar skin, most frequently the volar aspects of the fingers. It is charac- terized by annular erythema with air-filled bullae that rupture with lamellar peeling, because of the keratolysis of stratum corneum without cell infiltration. Slight pruritus or a burning sensation may precede the peeling, as well as pain in peeled areas.,3 Warm weather, water contact, friction or palmoplantar hyperhidrosis can be associated with its appearance. ${ }^{2}$

Differential diagnoses with dyshidrotic eczema, fungal infections, acral peeling skin syndrome and epidermolysis bullosa simplex located of the hands and feet may be considered. The lesions of queratolysis exfoliativa can last a few days and have a spontaneous resolution. ${ }^{2,3}$ No effective treatments have been described yet, but some patients show a favourable response to emollient creams. ${ }^{2,3}$ 


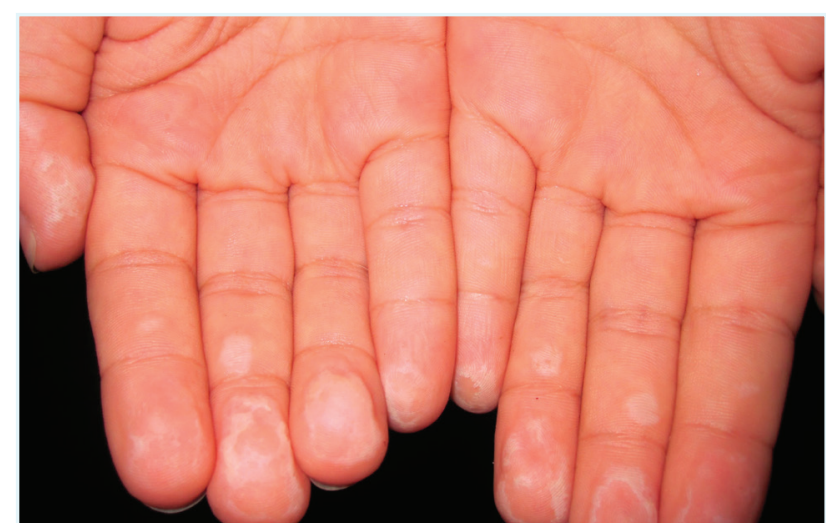

FIGURE 1. Air-filled blisters on the volar aspect of the extremities of fingers sugestive of keratolysis exfoliativa.

We highlight the importance of the recognition of this dermatosis, which is rarely documented despite is thought to be quite common. ${ }^{3}$

\section{ETHICAL DISCLOSURES}

CONFLICTS OF INTEREST: The authors have no conflicts of interest to declare.

FINANCING SUPPORT: This work has not received any contribution, grant or scholarship.

CONFIDENTIALITY OF DATA: The authors declare that they have followed the protocols of their work center on the publication of data from patients.

PATIENT CONSENT: Parental/guardian consent for publication was obtained.

PROVENANCE AND PEER REVIEW: Not commissioned; externally peer reviewed.

\section{RESPONSABILIDADESÉTICAS}

CONFLITOS DE INTERESSE: Os autores declaram a inexistência de conflitos de interesse na realização do presente trabalho.

FONTES DE FINANCIAMENTO: Não existiram fontes externas de financiamento para a realização deste artigo.

CONFIDENCIALIDADE DOS DADOS: Os autores declaram ter seguido os protocolos da sua instituição acerca da publicação dos dados de doentes.

CONSENTIMENTO: Consentimento para publicação obtido.

PROVENIÊNCIA E REVISÃO POR PARES: Não comissionado; revisão externa por pares.

\section{REFERENCES}

1. Caryon A. Desquamation estivale en aires des mains. Ann Dermatol Syphiligr. 1903; 4:283.

2. Chang YY, van der Velden J, van der Wier G, Diercks GFH, van Geel M, Coenraads PJ, et al. Keratolysis exfoliativa (dyshidrosis lamelosa sicca): a distinct peeling entity. $\mathrm{Br} J$ Dermatol. 2012; 167: 1076-84. doi: 10.1111/j.1365-2133.2012.11175.x.

3. Hausauer AK, Cohen DE. Case presentation. Keratolysis exfoliativa. Dermatol Online J. 2015;21:13030/qt6mv$338 n x$ 